\title{
Re-interpretation of progressive metamorphism, facies series, P-T-t path and exhumation model for the collisional orogenic belts
}

\author{
Shigenori Maruyama \\ Department of Earth and Planetary Sciences, Tokyo Institute of Technology, Tokyo 152-8551, JAPAN \\ For correspondence. E-mail: smaruyam@geo.titech.ac.jp
}

Recent discovery of ultra-high pressure (UHP) mineralogy, and descriptions of geology, petrology, geochronology and geochemistry of the Phanerozoic collisional orogens have changed the basic concepts of metamorphic facies series, P-Ttime path, progressive metamorphism, Barrovian-type metamorphism and tectonic model.

The Himalayan orogen has served as a world standard for the collisional orogenic belt for a long time, characterized by Barrovian-type metamorphism (intermediate-P type metamorphism within thestability field of plagioclase), tectonic overlapping of double-continental crust, and thermal relaxation with buoyant unroofing (England and Thompson 1984). Recent discovery of coesite-bearing eclogitein the western Himalaya and eclogites from the central to eastern Himalaya can not be explained bythepreviousmodels. In thefollowings, summarizing the new constraints on orogenic process, I try to explain the collision orogeny including Himalaya.

(1) Major structureasa sandwiched subhorizontal tectonic slice: a thin tectonic slice with P-T maximum at structural intermediate. TheUHP-HP unit is a few $\mathrm{km}$ thick slicecut on the top and bottom by normal and reverse faults, respectively. It is separated from the underlying and overlying low-gradeor low-P metamorphicrocks.

(2) The underlying unit is thermally metamorphosed to form andalusite-sillimanitemetamorphic rocksin somecases by the hot tectonic intrusion of UHP-HP rocks.

(3) Metamorphic facies series ranges from greenschist/ blueschist transition or blueschist, through epidote-amphibolite, quartz- and zoisite-eclogite, to dry eclogite facies with a sharp kink point, indicating anti-clockwise P-T path in the case of the highest- $P$ and $-T$ belt.

(4) The P-T-time path calculated by inclusion mineralogy in garnet combined with zoned garnet compositional profile shows the sameP-T path with the metamorphic facies series.

(5) Extensive hydration at mid-crustal level obliterated the pre-existing UHP-HP mineralogy, except mineral inclusions in garnet, zircon and omphacite.

(6) Zoned zircons with UHP-HP minerals mantled by latestage hydration with Barrovian minerals sare dated as ca. 30 m.y. older from that of hydration stageatrim, indicatinga slow tectonic exhumation.

(7) The mountain-building stage is not related to the exhumation of UHP-HP rocks to the mid-crustal level. The mountain-building, in the case of Himalaya, started at $9 \mathrm{Ma}$, ca. 16 m.y. after the Barrovian hydration at mid-crustal level.

(8) Combining above constraints, a tectonic extrusion model is themost probableprocess (Maruyama 1990, Maruyama etal. 1994, Maruyamaet al. 1996). (9) Previousinterpretation (e.g., England and Thompson 1984) of progressive metamorphism, facies series, P-T-t path are all quite different from those summarized here.

Most of present mineralogy exhibits the late-stage crustal metamorphism dueto extensivehydration underneath. Therole of water must be re-evaluated to mask the progressive nature of metamorphism duringsubduction.

\section{References}

England PC and AG Thompson. 1984. Pressure-Temperature-time path of regional metamorphism. I. Jour. Petrology 25: 894-928

Maruyama S. 1990. Denudation process of high-pressure metamorphic belt. Abst. $97^{\text {th }}$ Ann. Meeting Geol. Soc. Japan. 484p

Maruyama S, JG Liou and RY Zhang. 1994. Tectonic evolution of the ultrahigh-pressure (UHP) and high-pressure (HP) metamorphic belts from central China. Thelsland Arc 3: 112-121

Maruyama S, JG Liou and M Terabayashi. 1996. Blueschists and eclogites of the world and their exhumation. Intern Geol Rev 38: 485-594 